\title{
ADJUVANTS PLUS PHYTOSANITARY PRODUCTS AND THE EFFECTS ON THE PHYSICAL-CHEMICAL PROPERTIES OF THE SPRAY LIQUIDS
}

\author{
ADJUVANTES MAIS PRODUTOS FITOSSANITÁRIOS E OS EFEITOS NAS \\ PROPRIEDADES FÍSICO-QUÍMICAS DA CALDA
}

\section{Heli Heros Teodoro de ASSUNÇÃO ${ }^{1}$; Saulo Felipe Brockes CAMPOS ${ }^{2}$; Luciana Alves SOUSA ${ }^{3}$; Ernane Miranda LEMES $^{4}$; Cesar Henrique Souza ZANDONADI ${ }^{5}$; João Paulo Arantes Rodrigues da CUNHA ${ }^{6}$}

1. Professor Substituto na Universidade Federal de Mato Grosso, Instituto de Ciências Agrárias e Tecnológicas, Rondonópolis, MT, Brasil. heli.herosteodoro@gmail.com; 2. Mestre em Agronomia, Uberlândia, MG, Brasil; 3. Doutoranda em agronomia na Universidade Federal de Uberlândia, Instituto de Ciências Agrárias, Uberlândia, MG, Brasil; 4. Pós-doutorando na Universidade Federal de Uberlândia, Instituto de Ciências Agrárias, Uberlândia, MG, Brasil; 5. Doutor em Agronomia, Uberlândia, MG, Brasil; 6. Professor Associado na Universidade Federal de Uberlândia, Instituto de Ciências Agrárias, Uberlândia, MG, Brasil.

\begin{abstract}
The frequent tank mixing of phytosanitary products, adjuvants, and foliar fertilizers highlights the lack of information which sustains decisions about what products can be mixed for spray application. Thus, the aim of this study was to evaluate the physical and chemical characteristics of fungicides, herbicides, and insecticides in combination with some adjuvants on the Brazilian market. The experimental design was completely randomized and spray mixes of the phytosanitary products: fungicide (azoxystrobin+benzovindiflupir), herbicide (diamônio salt of $\mathrm{N}$-(phosponomethyl)) or insecticide (fenpropathrin) were evaluated in combination with adjuvants (mineral oil base, foliar fertilizer or lecithin + propionic acid), and in two application rates (95 and $52 \mathrm{~L} \mathrm{ha}^{-1}$ ); all with four replications. Surface tension, electrical conductivity, $\mathrm{pH}$, dynamic viscosity and density of spray mixes were evaluated. The adjuvants presented characteristics capable of significantly altering the physicochemical properties of the phytosanitary spray mixes, and thus, alter the biological effectiveness and efficiency of the spray applications. However, its effects are also dependent on the phytosanitary product added to the spray mix, which makes general recommendations a difficult task. The greatest $\mathrm{pH}$ reduction, as well as the greatest increase in electrical conductivity, were caused by the adjuvant lecithin + propionic acid. All phytosanitary products and adjuvants studied, associated or not, resulted in a reduction in the surface tension of the spray mix in relation to water. The magnitude of change of density and dynamic viscosity promoted by adjuvants was lower than the other characteristics evaluated.
\end{abstract}

KEYWORDS: Tank mixture. Fungicide. Insecticide. Herbicide.

\section{INTRODUCTION}

The mixture of phytosanitary products, adjuvants and foliar fertilizers for crop spray is a topic of interest for professionals in animal and plant production, and ecology, and with the legalization of this practice (BRAZIL, 2018) it became a theme that needs to be better studied and discussed. Although it is a routine practice in many crop farms, information and techniques that facilitate the selection of products to be mixed in the tank are lack.

The efficacy of phytosanitary products is directly linked to their reactions in the spray mix of application (CUNHA; ALVES, 2009). Thus, the improvement of application techniques depends on several factors, such as the knowledge of the environmental conditions at the time of application (low relative air humidity, high temperature, and wind speed above $10 \mathrm{~m} \mathrm{~s}^{-1}$ will negatively affect the efficiency of an application), the characteristics of each product and the physicochemical properties of the final phytosanitary spray mix.

These properties can be altered by the phytosanitary product as well as by the adjuvants added. According to Kissman (1997), adjuvant for agricultural uses is any substance without phytosanitary properties - except water - capable of facilitating application, reduce risks to the quality of the process and increase the efficiency of the products used. Among the main features that an adjuvant may present, there are the ability to change the time to drop evaporation, the size and the contact angle of the droplets, the area of leaf wetness and spreading of the product on the leaves, the electrical conductivity, $\mathrm{pH}$ and surface tension of the spray mix (MENDONÇA et al., 2007; CUNHA; ALVES, 2009; CUNHA et al., 2017). 
There are several types of adjuvants and among them, the oils (mineral or vegetable origin) are widely used in Brazilian agriculture. Vegetable oils are derived, in general, from the seed and plant parts processing (HESS, 1997), while the mineral oils come from the processes and distillation of crude oil. In accordance with Coradini et al. (2016), the use of mineral oils can cause a phytotoxic effect on plants, which can reduce the growth and interfere in plant development.

Another adjuvant that has a broad spectrum of use is phosphatidylcholine (lecithin) with propionic acid. Studies show that this adjuvant has as main characteristic the drift reduction due to an increase in the size of droplets generated during the applications (ALVES et al., 2018; ROSS Jr. et al., 2018). However, adverse effects from the use of this compound were observed by Sanches et al. (2018), such as a reduction in the effectiveness of the acaricide when used with this adjuvant.

In this sense, beyond the isolated effect of adjuvants and phytosanitary products, the in-tank mixture can cause undesirable changes in the spray mix and that need to be known to avoid risks to safety at work and environmental as well as economic losses for crop producers. Studies in this area are still scarce, mainly about the compatibility and sequence of mixing of different products applied in agricultural management (GAZZIERO, 2015). The existence of numerous formulations on the market, both of phytosanitary products and adjuvants, makes it complex to predict the interactions between them (CUNHA et al., 2017).

In this way, the aim of this work was to evaluate the physical and chemical characteristics of fungicides, herbicides, and insecticides spray mix in combination with common adjuvants on the Brazilian market in different application rates.

\section{MATERIAL AND METHODS}

The determination of physicochemical properties of the spray mix was performed at the Laboratory of Agricultural Mechanization of the Federal University of Uberlândia, Brazil, in the airconditioned environment at $25 \pm 2{ }^{\circ} \mathrm{C}$ temperature and $60 \pm 3 \%$ air relative humidity.

The experiment was designed as a completely randomized parcel with nine (9) treatments including fungicide, five (5) including herbicide, five (5) including insecticide and water control; treatments were conducted in four repetitions. The products were evaluated isolated and in two application rates ( 95 and $52 \mathrm{~L} \mathrm{ha}^{-1}$ ) and combined with the adjuvants (Table 1). All treatments are characterized in Table 2.

Table 1. Description of the phytosanitary products evaluated.

\begin{tabular}{|c|c|c|c|}
\hline Products & $\begin{array}{c}\text { Composition } \\
\text { (active ingredient concentration) }\end{array}$ & Formulation & $\begin{array}{l}\text { Dose } \\
\left(\text { ha }^{-1}\right)\end{array}$ \\
\hline Fungicide & Azoxystrobin $\left(300 \mathrm{~g} \mathrm{~kg}^{-1}\right)$; Benzovindiflupir $\left(150 \mathrm{~g} \mathrm{~kg}^{-1}\right)$. & $\begin{array}{l}\text { Dispersible } \\
\text { granules }\end{array}$ & $200 \mathrm{~g}$ \\
\hline Herbicide & Diammonium N-(phosphonate methyl)glycine $\left(445 \mathrm{~g} \mathrm{~L}^{-1}\right)$. & $\begin{array}{l}\text { Soluble } \\
\text { concentrate }\end{array}$ & $2 \mathrm{~L}$ \\
\hline Insecticide & Fenpropathrin $\left(300 \mathrm{~g} \mathrm{~L}^{-1}\right)$. & $\begin{array}{l}\text { Emulsifiable } \\
\text { concentrate }\end{array}$ & $0.085 \mathrm{~L}$ \\
\hline Adjuvants & $\begin{array}{c}\text { Composition } \\
\text { (active ingredient concentration) }\end{array}$ & Formulation & $\begin{array}{c}\text { Dose } \\
(\% \mathrm{v} / \mathrm{v})\end{array}$ \\
\hline MO & Mineral Oil (aliphatic hydrocarbons) $\left(428 \mathrm{~g} \mathrm{~L}^{-1}\right)$ & $\begin{array}{l}\text { Emulsifiable } \\
\text { concentrate }\end{array}$ & 0.5 \\
\hline FF & $\begin{array}{l}\text { Foliar Fertilizer - N }\left(34.5 \mathrm{~g} \mathrm{~L}^{-1}\right) ; \mathrm{P}_{2} \mathrm{O}_{5}\left(207 \mathrm{~g} \mathrm{~L}^{-1}\right) \text {; acidulant }(30.8 \mathrm{~g} \\
\left.\mathrm{L}^{-1}\right) \text {; silicone surfactant }\left(57.5 \mathrm{~g} \mathrm{~L}^{-1}\right) \text {. }\end{array}$ & Suspension & 0.05 \\
\hline SA & Synthetic Adjuvant (lecithin + propionic acid) $\left(713 \mathrm{~g} \mathrm{~L}^{-1}\right)$ & $\begin{array}{l}\text { Emulsifiable } \\
\text { concentrate }\end{array}$ & 0.5 \\
\hline
\end{tabular}

Table 2. The composition of the spray mix treatments.

\begin{tabular}{cc}
\hline \multicolumn{1}{c}{ Fungicides } & Abbreviation \\
\hline Water + fungicide $\left(0.89 \mathrm{~g} \mathrm{~L}^{-1}\right)+$ mineral oil $(0.5 \% \mathrm{v} / \mathrm{v})(5 \mathrm{~mL} \mathrm{~L}-1)$ & $95^{*}+\mathrm{MO}$ \\
Water + fungicide $\left(0.89 \mathrm{~g} \mathrm{~L}^{-1}\right)+$ foliar fertilizer $(0.05 \% \mathrm{v} / \mathrm{v})\left(0.5 \mathrm{~mL} \mathrm{~L}^{-1}\right)$ & $95+\mathrm{FF}$ \\
Water + fungicide $\left(0.89 \mathrm{~g} \mathrm{~L}^{-1}\right)+$ synthetic adjuvant $(0.5 \% \mathrm{v} / \mathrm{v})\left(5 \mathrm{~mL} \mathrm{~L}^{-1}\right)$ & $95+\mathrm{SA}$ \\
Water + fungicide $\left(0.89 \mathrm{~g} \mathrm{~L}^{-1}\right)$ & 95
\end{tabular}




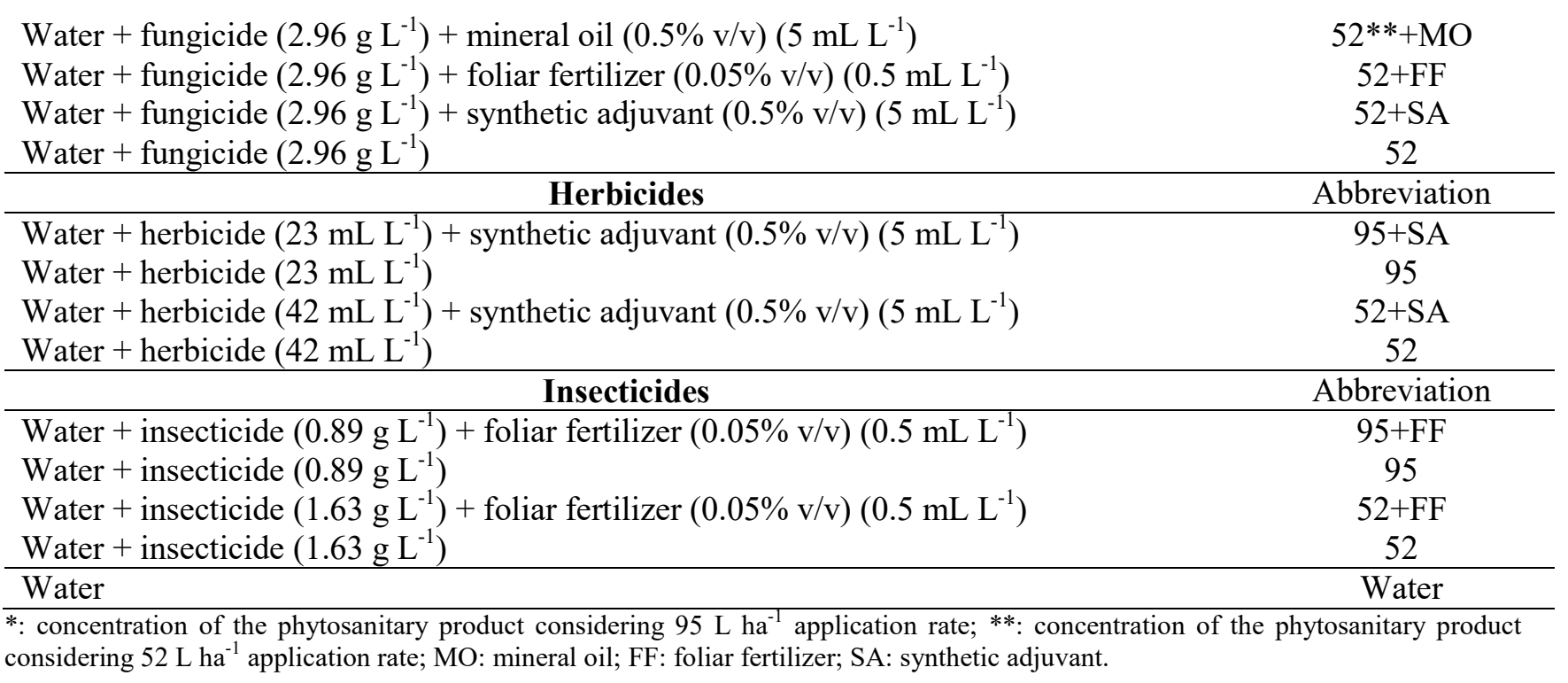

The mineral oil adjuvant is recommended to increase product spread and penetration in the plant leaf. The foliar fertilizer adjuvant has silicone in its composition and acidulants, which is recommended to reduce spray mix $\mathrm{pH}$ and droplet spread. The adjuvant composed of lecithin + propionic acid is recommended to reduce surface tension, standardize droplets, reduce drift and buffer the spray mix solution.

The characteristics evaluated in the spray mixes were superficial tension, electrical conductivity, dynamic viscosity, spray mix $\mathrm{pH}$ and density, as methodologies used by Cunha and Alves (2009) and Cunha et al. (2017).

The surface tension was determined using a tensiometer (Kruss, K6) by the Du Nuoy ring method. In this method, a ring is placed on the surface of the liquid and the force required to detach the ring from the surface measured. Spray mix $\mathrm{pH}$ and conductivity were measured directly on the solutions using a $\mathrm{pH}$ meter and a portable conductivimeter (AKSO, AK59), previously calibrated on standard solutions provided by the manufacturers.

The dynamic viscosity was determined using a rotational viscometer (QUIMIS Microprocessed, Q860M21), which allowed measure electronically the twisting force through the rotation of the cylinder (reading head) immersed in the sample. The resistance to rotation of the rotor at zero (0) and at $60 \mathrm{rpm}$ was used to determine the viscosity of the spray mix of each treatment.

To determine spray mix density four volumetric balloon flasks $(100 \mathrm{~mL})$ were identified and their masses determined with precision. One hundred (100) $\mathrm{mL}$ of each treatment was added to these flasks and their new masses were determined. Through the difference between the mass of the flask full and empty, and the known volume (100 $\mathrm{mL}$ ), it was possible to calculate the density of the sample.

The data were submitted to tests of normality of residues by Shapiro-Wilk's test and homogeneity of variances by Levene's test. After presupposition acceptance $(\mathrm{p}>0.05)$, analysis of variance ( $F$ test) was performed and when significant differences were observed the treatments were compared by Tukey's test at 0.05 significance level. All analyses were performed using the $\mathrm{R}$ statistical program (R CORE TEAM, 2018).

\section{RESULTS AND DISCUSSION}

The physical and chemical characteristics of the fungicide, insecticide and herbicide spray mixes showed differences for all the variables analyzed (Table 3, 4 and 5), demonstrating that the spray solution is significantly affected by the addition of adjuvants.

In general, the spray mixes studied presented interference on the $\mathrm{pH}$ of the solutions in relation to water treatment. Changes in $\mathrm{pH}$ may interfere with the biological effects of phytosanitary products as demonstrated by Cunha and Alves (2009). The reduction in $\mathrm{pH}$ reduces the alkaline hydrolysis of sensitive products such as glyphosate herbicide and consequently improving the spray efficiency (CUNHA et al., 2017). 
Table 3. Physical and chemical properties of the fungicide spray mixes and water.

\begin{tabular}{|c|c|c|c|c|c|}
\hline Spray mix ${ }^{\Psi}$ & $\mathrm{pH}$ & $\begin{array}{l}\text { Elet. conduct. } \\
\qquad\left(\mu \mathrm{S} \mathrm{cm}^{-1}\right)\end{array}$ & $\begin{array}{l}\text { Density } \\
\left(\mathrm{g} \mathrm{cm}^{-3}\right)\end{array}$ & $\begin{array}{l}\text { Dynamic visc. } \\
\left(\mathrm{mPa} \mathrm{s}^{-1}\right)\end{array}$ & $\begin{array}{l}\text { Superf. tension } \\
\quad\left(\mathrm{mN} \mathrm{m}^{-1}\right)\end{array}$ \\
\hline $95+\mathrm{MO}$ & $9.70 \mathrm{a}$ & $232 \mathrm{f}$ & $0.9952 \mathrm{de}$ & $0.96 \mathrm{de}$ & $33.0 \mathrm{~cd}$ \\
\hline $95+\mathrm{FF}$ & $7.25 \mathrm{~b}$ & $342 \mathrm{~d}$ & $0.9975 \mathrm{~cd}$ & $0.94 \mathrm{e}$ & $30.6 \mathrm{~b}$ \\
\hline $95+\mathrm{SA}$ & $4.25 \mathrm{e}$ & $664 \mathrm{~b}$ & $0.9967 \mathrm{cde}$ & $1.01 \mathrm{ab}$ & $32.8 \mathrm{~cd}$ \\
\hline 95 & $9.57 \mathrm{a}$ & $133 \mathrm{~g}$ & $0.9945 \mathrm{e}$ & $0.98 \mathrm{~cd}$ & $33.0 \mathrm{~cd}$ \\
\hline $52+\mathrm{MO}$ & $9.75 \mathrm{a}$ & $305 \mathrm{e}$ & $1.0007 \mathrm{~b}$ & $0.95 \mathrm{de}$ & $33.5 \mathrm{de}$ \\
\hline $52+\mathrm{FF}$ & $6.85 \mathrm{c}$ & $528 \mathrm{c}$ & $0.9982 \mathrm{bc}$ & $0.88 \mathrm{f}$ & $28.8 \mathrm{a}$ \\
\hline $52+\mathrm{SA}$ & $4.92 \mathrm{~d}$ & $1448 \mathrm{a}$ & 0.9962 cde & $1.03 \mathrm{a}$ & $32.0 \mathrm{bc}$ \\
\hline 52 & $9.67 \mathrm{a}$ & $282 \mathrm{e}$ & $1.0007 \mathrm{~b}$ & $0.96 \mathrm{de}$ & $35.0 \mathrm{e}$ \\
\hline Water & $6.85 \mathrm{c}$ & $16 \mathrm{~h}$ & $1.0240 \mathrm{a}$ & $0.99 \mathrm{bc}$ & $71.6 \mathrm{f}$ \\
\hline C.V. (\%) & 1.10 & 2.38 & 0.11 & 1.33 & 1.67 \\
\hline $\mathrm{Fc}$ & $2584^{*}$ & $6617^{*}$ & $273.8^{*}$ & $44.3^{*}$ & $1874.7^{*}$ \\
\hline $\mathrm{W}$ & $0.934 * *$ & $0.939 * *$ & $0.934 * *$ & $0.938^{* *}$ & $0.966^{*}$ \\
\hline $\mathrm{F}_{\text {Levene }}$ & $0.795^{*}$ & $2.365^{* *}$ & $0.281^{*}$ & $1.429^{*}$ & $0.984 *$ \\
\hline
\end{tabular}

${ }^{\Psi}$ Treatment descriptions according to Table 2; Averages followed by similar letters in column do not differ by the Tukey test (p<0.05); Fc: value of F calculated; FLevene = Levene test statistic; $\mathrm{W}=$ Shapiro-Wilk test statistic; C.V. = coefficient of variation. Values followed by “*” or “**” are significant at $5 \%$ or $1 \%$ of probability, respectively.

Table 4. Physical and chemical properties of the herbicide spray mixes and water.

\begin{tabular}{cccccc}
\hline Spray mix & कH & $\begin{array}{c}\text { Elet. conduct. } \\
\left(\mu \mathrm{S} \mathrm{cm}^{-1}\right)\end{array}$ & $\begin{array}{c}\text { Density } \\
\left(\mathrm{g} \mathrm{cm}^{-3}\right)\end{array}$ & $\begin{array}{c}\text { Dynamic visc. } \\
\left(\mathrm{mPa} \mathrm{s}^{-1}\right)\end{array}$ & $\begin{array}{c}\text { Superf. tension } \\
\left(\mathrm{mN} \mathrm{m}^{-1}\right)\end{array}$ \\
\hline $95+\mathrm{SA}$ & $4.98 \mathrm{e}$ & $10151 \mathrm{~d}$ & $1.015 \mathrm{c}$ & $1.02 \mathrm{~b}$ & $31.5 \mathrm{a}$ \\
95 & $6.73 \mathrm{~b}$ & $11242 \mathrm{c}$ & $0.9922 \mathrm{e}$ & $0.98 \mathrm{c}$ & $35.6 \mathrm{~b}$ \\
$52+\mathrm{SA}$ & $5.43 \mathrm{~d}$ & $17034 \mathrm{~b}$ & $1.0208 \mathrm{~b}$ & $1.05 \mathrm{a}$ & $30.5 \mathrm{a}$ \\
52 & $6.58 \mathrm{c}$ & $18525 \mathrm{a}$ & $0.9952 \mathrm{~d}$ & $1.00 \mathrm{bc}$ & $36.5 \mathrm{~b}$ \\
Water & $6.85 \mathrm{a}$ & $16 \mathrm{e}$ & $1.0240 \mathrm{a}$ & $0.99 \mathrm{c}$ & $71.6 \mathrm{c}$ \\
\hline C.V. $(\%)$ & 0.85 & 0.01 & 0.09 & 1.03 & 1.19 \\
Fc & $905^{*}$ & $80914219^{*}$ & $1104.7^{*}$ & $33.9 *$ & $4261^{*}$ \\
W & $0.916^{* *}$ & $0.933^{*}$ & $0.924^{*}$ & $0.933^{*}$ & $0.941^{*}$ \\
$\mathrm{~F}_{\text {Levene }}$ & $0.400^{*}$ & $3.211^{* *}$ & $0.300^{*}$ & $2.204^{*}$ & $0.600^{*}$ \\
\hline
\end{tabular}

${ }^{\Psi}$ Treatment descriptions according to Table 2; Averages followed by similar letters in column do not differ by the Tukey test ( $\mathrm{p}<0.05$ ); Fc: value of $\mathrm{F}$ calculated; FLevene $=$ Levene test statistic; $\mathrm{W}=$ Shapiro-Wilk test statistic; C.V. = coefficient of variation. Values followed by "**" or "**” are significant at $5 \%$ or $1 \%$ of probability, respectively.

Table 5. Physical and chemical properties of the insecticide spray mixes and water.

\begin{tabular}{cccccc}
\hline Spray mix & $\mathrm{pH}$ & $\begin{array}{c}\text { Elet. conduct. } \\
\left(\mu \mathrm{S} \mathrm{cm}^{-1}\right)\end{array}$ & $\begin{array}{c}\text { Density } \\
\left(\mathrm{g} \mathrm{cm}^{-3}\right)\end{array}$ & $\begin{array}{c}\text { Dynamic visc. } \\
\left(\mathrm{mPa} \mathrm{s}^{-1}\right)\end{array}$ & $\begin{array}{c}\text { Superf. tension } \\
\left(\mathrm{mN} \mathrm{m}^{-1}\right)\end{array}$ \\
\hline $95+\mathrm{FF}$ & $3.45 \mathrm{~d}$ & $434 \mathrm{a}$ & $0.9981 \mathrm{~d}$ & $0.92 \mathrm{~b}$ & $28.1 \mathrm{a}$ \\
95 & $7.70 \mathrm{a}$ & $13 \mathrm{~d}$ & $0.9967 \mathrm{e}$ & $0.93 \mathrm{~b}$ & $35.5 \mathrm{~b}$ \\
$52+\mathrm{FF}$ & $3.92 \mathrm{~d}$ & $338 \mathrm{~b}$ & $1.0948 \mathrm{a}$ & $0.93 \mathrm{~b}$ & $28.1 \mathrm{a}$ \\
52 & $5.82 \mathrm{c}$ & $17 \mathrm{c}$ & $1.0673 \mathrm{~b}$ & $0.94 \mathrm{~b}$ & $34.2 \mathrm{~b}$ \\
Water & $6.85 \mathrm{~b}$ & $16 \mathrm{c}$ & $1.0240 \mathrm{c}$ & $0.99 \mathrm{a}$ & $71.6 \mathrm{c}$ \\
\hline C.V. $(\%)$ & 4.25 & 0.94 & 0.01 & 1.24 & 2.6 \\
Fc & $241^{*}$ & $72113^{*}$ & $925826^{*}$ & $25.9^{*}$ & $1265.8^{*}$ \\
W & $0.951^{*}$ & $0.977^{*}$ & $0.871^{* *}$ & $0.95^{*}$ & $0.925^{*}$ \\
$\mathrm{~F}_{\text {Levene }}$ & $4.7^{* *}$ & $0.32^{*}$ & $0.321^{*}$ & $1.23^{*}$ & $0.19^{*}$ \\
\hline
\end{tabular}

${ }^{\Psi}$ Treatment descriptions according to Table 2; Averages followed by similar letters in column do not differ by the Tukey test (p<0.05); Fc: value of F calculated; FLevene $=$ Levene test statistic; $\mathrm{W}=$ Shapiro-Wilk test statistic; C.V. = coefficient of variation. Values followed by “*” or "***" are significant at $5 \%$ or $1 \%$ of probability, respectively. 
The addition of $\mathrm{MO}$ adjuvant to the higher fungicide concentration, or even the fungicide alone (Table 3: $95+\mathrm{MO}, 95,52+\mathrm{MO}, 52$ ), presented high values of spray mix $\mathrm{pH}$ in relation to other treatments. This demonstrates the alkaline nature of this fungicide and the characteristic of not reducing the spray mix $\mathrm{pH}$ by the mineral oil used. The effects of the addition of SA and FF on spray mix $\mathrm{pH}$ are presented in Tables 3, 4 and 5 and show the effect of these compounds on the reduction of the spray mix $\mathrm{pH}$. This is due to the presence of propionic acid in the SA and the acidulant in the FF.

However, Sanches et al. (2018) evaluating an adjuvant based on lecithin + propionic acid showed that the drastic change in the $\mathrm{pH}$ of the spray solution caused by this product can be associated with the reduction in the effectiveness of pest control in citrus. Therefore, it is necessary to analyze the optimal $\mathrm{pH}$ range for each phytosanitary case in order to verify their compatibility with the adjuvant. Also, the effects of the adjuvant mixed with the phytosanitary product are dependent on the application rate, for example, the effect of propionic acid in the fungicide presented pronounced $\mathrm{pH}$ reduction at the highest rate of application $(95+$ AS).

Regarding the electrical conductivity, the results reinforce the idea that this characteristic is affected by the phytosanitary product formulation and, mainly, by the ions present, its concentration and valences (CUNHA et al., 2017). The values showed that the herbicide diammonium $\mathrm{N}$ (phosphonate methyl)glycine alone has a great ability to elevate the spray electrical conductivity, mainly in the lower rate of application, where it is more concentrated. Among the adjuvants in fungicide, the lecithin + propionic acid presented the most elevated electrical conductivity and the mineral oil the lowest increase. In the insecticide spray mix, little changes were observed for this characteristic, but foliar fertilizer considerable increase in electrical conductivity, possibly due to the presence of ions.

Electrical conductivity is relevant, especially when using the electrostatic technique of application of phytosanitary products. According to Patel et al. (2017), higher values of electrical conductivity are beneficial to this technique because it alters the amplitude of the electrification of the droplets with a direct impact on the droplet attraction and greater deposition on the target and, consequently, higher biological effectiveness. Sasaki et al. (2015) observed that, in general, the addition of adjuvants to spray solutions has the ability to change the values of electrical conductivity, increasing it and consequently the mass/charge ratio of the droplet, which can interfere in electrostatic applications.

All spray mix tested showed lower values of surface tension in relation to water (Tables 3, 4 and 5). It is expected that an adjuvant for agricultural use, with surfactants characteristics, decrease the surface tension of the spray mix with the objective to improve the droplet spreading, retention and the adhesiveness on the leaf surface and, consequently, the leaf wettability (CUNHA et al., 2017; ALVES, CUNHA, 2009.

The values in Table 3 (fungicide) also demonstrated that the FF, for the treatment of lower application rate, was more effective in the reduction of surface tension. This probably occurred due to the presence of silicone in its composition. Studies conducted by Iost and Raetano (2010) demonstrated that adjuvants containing silicone have a great effect on the reduction of surface tension, which contributes to increased target coverage.

The spray mix composed by herbicide or insecticide (Tables 4 and 5) presented better results only when adjuvant (AS or FF) was added. The surface tension is not determined by the origin of the oil (mineral or vegetable), but by the quality and quantity of emulsifier added to its formulation (MENDONÇA et al., 2007).

The surfactants, when added to water, make arrangements so that the polar end of these molecules is facing the water, and the other end facing the atmosphere or to the interface on which the liquid is in contact. This arrangement of molecules, called micelles, however, does not occur in any concentration, only from a minimum concentration, called critical micellar concentration, which is a characteristic of each compound (IOST; RAETANO, 2010).

In relation to the density and the dynamic viscosity, the results showed that the majority of the adjuvants studied exerted some influence on these characteristics, which may contribute to the increased security of applications by possible reducing droplet drift. These characteristics may affect mainly the droplet's size and, consequently, the risk of drift (CUNHA et al., 2017). It is emphasized that another possible action of adjuvants may be on the spectrum of droplets sprayed, in particular, the uniformity of size, which may also influence the risk of drift.

In fungicides spray solutions with lecithin + propionic acid or FF adjuvant the viscosity of the spray solution numerically increased and decreased, respectively. However, this variation of viscosity provided by the addition of adjuvants was not 
significant $(\mathrm{p}>0.05)$. Gandolfo et al. (2013) showed the potential of lecithin + propionic acid in the reduction of spray drift and, in part, this can be explained by the increase in the viscosity of the spray mix. In the herbicide solutions, the effect was similar to what was observed for the fungicide spray solutions. In the insecticide spray solutions, there was no influence of the adjuvant added.

In relation to the spray mix density, the magnitude of these changes was relatively small, which can result in a very small effect on the weight of the droplets. This occurs in general due to low recommended concentrations of adjuvants in relation to large quantities of water. Similar results were found by Cunha and Alves (2009). According to these authors, to achieve a significant increase in density would be necessary to greatly increase the concentration, which would increase application costs.

Due to this complexity and diversity of reactions that can happen between phytosanitary products and adjuvants, it is not possible to generalize the results found to other formulations available in the market, thus, constant studies must be carried to update the information about mixing in tank of products used for crop management, since new products are regularly released.

\section{CONCLUSIONS}

The adjuvants presented characteristics that significantly alter the physicochemical properties of phytosanitary spray mixes, and thus can alter the biological effectiveness and the efficiency of the applications. Therefore, their use is important to achieve the best performance of the spray mix, contributing to agriculture efficient, economic and more sustainable. However, its effects are also dependent on the phytosanitary product added to the spray mix.

The greatest reduction in spray mix $\mathrm{pH}$, as well as the greatest increase in electrical conductivity, were caused by the adjuvant lecithin + propionic acid. All plant phytosanitary products and adjuvants, associated or not, resulted in reductions in the surface tension of the spray mix in relation to water. The magnitude of the density and viscosity change promoted by the adjuvants was lower than the other characteristics evaluated.

\section{ACKNOWLEDGMENTS}

To the Federal University of Uberlândia (UFU), LAMEC-ICIAG, Campus Uberlândia for the infrastructure conceded and to the Coordination of Superior Level Staff Improvement (CAPES) for the scholarships granted.

RESUMO: A realização frequente de misturas em tanque de produtos fitossanitários, adjuvantes e fertilizantes foliares traz à tona a carência de informações que amparem as decisões sobre quais produtos podem ser misturados. O objetivo deste trabalho foi avaliar características físicas e químicas de caldas fungicidas, herbicidas e inseticidas em combinação com alguns adjuvantes do mercado. O delineamento experimental utilizado foi inteiramente casualizado, sendo avaliadas diferentes caldas com o fungicida azoxistrobina+benzovindiflupir, herbicida sal de diamônio de $\mathrm{N}$-(phosponomethyl) e inseticida fenpropatrina, em combinação com adjuvantes a base de óleo mineral, fertilizante foliar e lecitina de soja+ácido propiônico, considerando duas taxas de aplicação ( 95 e $52 \mathrm{~L} \mathrm{ha}^{-1}$ ), todos os tratamentos com quatro repetições. Foram avaliadas as seguintes características: tensão superficial, condutividade elétrica, $\mathrm{pH}$, viscosidade dinâmica e densidade. Os adjuvantes apresentaram características capazes de alterar significativamente as propriedades físico-químicas das caldas fitossanitárias, podendo, assim, alterar a eficácia biológica e a eficiência das aplicações. Contudo, seu efeito também é dependente do produto fitossanitário adicionado à calda, o que dificulta generalizações. A maior redução do $\mathrm{pH}$, bem como o maior aumento na condutividade elétrica da calda, foram ocasionados pelo adjuvante lecitina+ácido propiônico. Todos os produtos fitossanitários e adjuvantes, de forma associada ou não, provocaram redução na tensão superficial da calda em relação à água. A magnitude das alterações de densidade e viscosidade dinâmica promovida pelos adjuvantes foi inferior às demais características avaliadas.

PALAVRAS-CHAVE: Mistura em tanque. Fungicida. Inseticida. Herbicida.

\section{REFERENCES}


ALVES, G. S.; KRUGER, G. R.; CUNHA, J. P. A. R. Spray drift and droplet spectrum from dicamba sprayed alone or mixed with adjuvants using air-induction nozzles. Pesquisa Agropecuária Brasileira, Brasilia, v. 53, n. 6, p. 693-702, 2018. http://dx.doi.org/10.1590/s0100-204x2018000600005

BRASIL. Instrução Normativa $n^{\circ} 40$ de 11 de Outubro de 2018. Estabelecer regras complementares a emissão da receita agronômica. Diário Oficial [da] República Federativa do Brasil, Poder Executivo, Brasília, DF, 15 out. 2018. Seção 1, p. 3.

CORADINI, C.; PICCININI, F.; REIMCHE, G. B.; COSTA, I. F. D. da; MACHADO, S. L. O. Efeito de óleo essencial de laranja associados a fungicidas no controle de doenças foliares do trigo. Summa

Phytopathologica, Botucatu, v. 42, n. 1, p. 105-106, 2016. http://dx.doi.org/10.1590/0100-5405/2020

CUNHA, J. P. A. R.; ALVES, G. S. Características físico-químicas de soluções aquosas com adjuvantes de uso agrícola. Interciencia, Caracas, v. 34, n. 9, p. 655-659, 2009.

CUNHA, J. P. A. R.; ALVES, G. S.; MARQUES, R. S. Tensão superficial, potencial hidrogeniônico e condutividade elétrica de caldas de produtos fitossanitários e adjuvantes. Revista Ciência Agronômica, Fortaleza, v. 48, n. 2, p. 261-270, 2017. http://dx.doi.org/10.5935/1806-6690.20170030

GANDOLFO, M. A.; CHECHETTO, R. G.; CARVALHO, F. K.; GANDOLFO, U. D.; MORAES, E. D. Influência de pontas de pulverização e adjuvantes na deriva em caldas com glyphosate. Revista Ciência Agronômica, Fortaleza, v. 44, n. 3, p. 474-480, 2013.

GAZZIERO, D. L. P. Misturas de agrotóxicos em tanque nas propriedades agrícolas do Brasil. Planta Daninha, Viçosa, v. 33, n. 1, p. 83-92, 2015. http://dx.doi.org/10.1590/S0100-83582015000100010.

GODINHO JUNIOR, J. D.; RUAS, R. A. A.; REIS, M. R. D.; CARVALHO FILHO, A.; FARIA, V. R. Reduction in the spray drift of 2, 4-D in tomato using hydraulic nozzles with air induction and LI-700 adjuvant. Pesquisa Agropecuária Tropical, Brasília, v. 48, n. 2, p. 134-139, 2018.

HESS, F. D. Adjuvants. In: Herbicide action course, 1997, West Lafayette. Proceedings... West Lafayette: Purdue University, 1997. p. 38-61.

IOST, C. A. R.; RAETANO, C. G. Tensão superficial dinâmica e ângulo de contato de soluções aquosas com surfatantes em superfícies artificiais e naturais. Engenharia Agrícola, Jaboticabal, v. 30, n. 4, p. 670-680, 2010. http://dx.doi.org/10.1590/S0100-69162010000400011

KISSMANN, K. G. Adjuvantes para caldas de produtos fitossanitários. In: GUEDES, J. V. C.; DORNELLES, S. B. (Org.). Tecnologia e segurança na aplicação de agrotóxicos: novas tecnologias. Santa Maria: Departamento de Defesa Fitossanitária, sociedade de Agronomia de Santa Maria, 1998. p. 39-51.

MENDONÇA, C. G.; RAETANO, C. G.; MENDONÇA, C. G. Tensão superficial estática de soluções aquosas com óleos minerais e vegetais utilizados na agricultura. Engenharia Agrícola, Jaboticabal, n. 27, p. 16-23, 2007. https://doi.org/10.1590/S0100-69162007000200003

PATEL, M. K.; PRAVEEN, B.; SAHOO, H. K.; PATEL, B.; KUMAR, A.; SINGH, M.; NAYAK, M. K.; RAJAN, P. An advance air-induced air-assisted electrostatic nozzle with enhanced performance. Computers and Electronics in Agriculture, Gainesville, v. 135, p. 280-288, 2017.

https://doi.org/10.1016/j.compag.2017.02.010

R CORE TEAM. R: a language and environment for statistical computing. R Foundation for Statistical Computing, Vienna, Austria, 2018. 
SANCHES, J. J.; FERREIRA, M. D. C.; ANDRADE, D. J. D. Impact of Rainfalls on the Acaricide Propargite with and without addition of adjuvants for the control of the mite Brevipalpus yothersi. Revista Brasileira de Fruticultura, Jaboticabal, v. 40, n. 1, 2018. http://dx.doi.org/10.1590/0100-29452018775

SASAKI, R. S.; TEIXEIRA, M. M.; SANTIAGO, H.; MADUREIRA, R. P.; MACIEL, C. F. S.;

FERNANDES, H. C. Adjuvantes nas propriedades físicas da calda, espectro e eficiência de eletrificação das gotas utilizando a pulverização eletrostática. Ciência Rural, Santa Maria, v. 45, n. 2, p. 274-279, 2015. https://doi.org/10.1590/0103-8478cr20131604 